\title{
Mikrocząsteczki błon komórkowych - nowy gracz na scenie chorób układu sercowo-naczyniowego
}

\author{
Cell-derived microparticles - a new player on cardiovascular stage
}

\author{
Aleksandra Gąsecka, Mariusz Tomaniak \\ I Katedra i Klinika Kardiologii Warszawskiego Uniwersytetu Medycznego
}

\section{Streszczenie}

Mikrocząsteczki błon komórkowych (MP) uważane są za biomarkery świadczące o aktywacji płytek krwi i nasileniu procesów zapalnych in vivo. Zwiększenie stężenia poszczególnych podtypów MP, w tym pochodzących z płytek krwi, komórek śródbłonka naczyń i leukocytów, zaobserwowano u osób z chorobą niedokrwienną serca, udarem mózgu i chorobą tętnic obwodowych. Zauważono, że w przebiegu wymienionych jednostek chorobowych stężenie MP koreluje ze stadium rozwoju choroby. Według niektórych autorów MP pośrednio przyczyniają się do rozwoju miażdżycy tętnic i jej powikłań. Coraz więcej dowodów naukowych wskazuje na możliwość potencjalnego wykorzystania MP w diagnostyce najważniejszych powikłań miażdżycy tętnic i prognozowaniu ryzyka w przebiegu chorób układu sercowo-naczyniowego (CVD), jak również w ocenie skuteczności leczenia przeciwpłytkowego kwasem acetylosalicylowym i klopidogrelem. Obecnie trwają badania mające na celu opracowanie standardowych metod izolacji i oznaczania MP w płynach ustrojowych, co stworzy możliwość pełniejszego zrozumienia ich roli w patogenezie CVD, a także wykorzystania tych nowych, obiecujących biomarkerów w codziennej praktyce klinicznej.

Słowa kluczowe: mikrocząsteczki, biomarkery, choroby układu sercowo-naczyniowego, miażdżyca

Folia Cardiologica 2016; 11, 2: 128-133

\section{Wstęp}

Choroby układu krążenia są główną przyczyną przedwczesnej umieralności Polaków, odpowiadając za 45\% wszystkich zgonów u osób poniżej 65. roku życia [1]. Wyniki badania epidemiologicznego „Nadciśnienie tętnicze oraz inne czynniki ryzyka chorób serca i naczyń w Polsce" (NATPOL 2011), którego celem była ocena częstości występowania czynników ryzyka sercowo-naczyniowego w populacji polskiej w wieku od 18 do 79 lat dowiodły, że 61\% dorosłych Polaków (18 mln osób) ma hiperlipidemię, zdefiniowaną jako stężenie cholesterolu całkowitego powyżej $190 \mathrm{mg} / \mathrm{dl}$, $32 \%(10,5 \mathrm{mln})$ choruje na nadciśnienie tętnicze, 27\% (8 $\mathrm{mln}$ ) deklaruje czynny nikotynizm, 22\% jest otyłych (6,5 mln), a 5\% (1,6 mln) choruje na cukrzyce typu 2 [2]. Wy- mienione stany kliniczne należą do głównych, potencjalnie modyfikowalnych czynników ryzyka rozwoju miażdżycy tętnic oraz jej następstw w postaci zawału serca, udaru mózgu i choroby tętnic obwodowych. Biorąc pod uwage społeczną i ekonomiczną wagę tych problemów, ważnym kierunkiem prowadzonych obecnie badań nad indywidualizacją diagnostyki w ocenie ryzyka sercowo-naczyniowego i odpowiedzi na terapię jest poszukiwanie nowych biomarkerów, które pozwoliłyby monitorować funkcję śródbłonka naczyniowego, odzwierciedlającą nasilenie leżących u podłoża miażdżycy procesów zapalnych [3], oraz ocenić stopień aktywacji płytek krwi, świadczący o ryzyku rozwoju jej najgroźniejszych powikłań [4]. Wśród potencjalnych biomarkerów, które spełniają oba powyższe kryteria, znajdują się mikrocząsteczki błon komórkowych (MP, microparticles). 


\section{Charakterystyka mikrocząsteczek błon komórkowych}

Mikrocząsteczki to fragmenty błon powierzchniowych wielkości 50-1000 nm, uwalniane z komórek eukariotycznych do płynów ustrojowych podczas fizjologicznego procesu ich dojrzewania [5]. Ich obecność stwierdzono w osoczu, krwi pełnej, krwi pępowinowej, moczu, ślinie i płynie mózgowo-rdzeniowym [6]. Pęcherzyki te nie posiadają jądra komórkowego, zawierają natomiast materiał cytoplazmatyczny komórek macierzystych. Na swojej powierzchni MP eksponują pochodzące z komórek macierzystych markery powierzchniowe (CD, clusters of differentiation), pozwalające na identyfikację ich pochodzenia [6]. Dzięki obecności w ich błonie cząsteczek adhezji międzykomórkowej 1 (ICAM-1, intercellular adhesion molecule 1) i cząsteczki adhezji komórkowej naczyń 1 (VCAM-1, vascular cell adhesion molecule 1) MP łączą się z innymi komórkami i uczestniczą w międzykomórkowym transporcie białek receptorowych i enzymatycznych, cytokin i czynników wzrostu, a także kwasów: mikro rybonukleinowego (miRNA, micro-ribonucleic acid), matrycowego RNA (mRNA) i deoksyrybonukleinowego (DNA, deoxyribonucleic acid) [5, 6]. Zaobserwowano, że dostarczony przez MP do monocytów i komórek śródbłonka mRNA może podlegać w tych komórkach procesowi translacji [7], a mikroRNA bierze w nich udział w epigenetycznej regulacji ekspresji genów [8]. Mikrocząsteczki płytkowe (PMP, platelet microparticles) i pochodzące z megakariocytów stanowią 70-90\% obecnych we krwi MP [9]. Postuluje się, że w stanie fizjologicznym pełnią one ważną funkcję w procesie krzepnięcia, gdyż analogicznie do płytek krwi eksponują na swojej powierzchni miejsca wiążące dla kolagenu i czynnika von Willebranda (vWf, von Willebrand factor) [10]. Na stężenie MP w osoczu wpływ mają takie czynniki konstytucjonalne, jak wiek i płeć - podwyższone stężenie stwierdzono w populacji dziecięcej i geriatrycznej, a także u mężczyzn [6]. Wyższe stężenie MP występuje także po intensywnym wysiłku fizycznym, u kobiet w ciąży, u osób otyłych i uzależnionych od nikotyny [6]. W warunkach prokoagulacyjnych lub w przebiegu przewlekłych stanów zapalnych dochodzi do zwiększonego uwalniania MP pochodzących z aktywowanych lub ulegających apoptozie płytek krwi, leukocytów, erytrocytów, komórek śródbłonka naczyń i komórek mięśni gładkich [11]. Molekularnym sygnałem poprzedzającym przebudowę błony komórkowej z następowym uwalnianiem MP jest wewnątrzkomórkowe podwyższenie stężenia jonów wapnia w odpowiedzi na takie bodźce, jak zwiększenie siły ścinającej, wolne rodniki tlenowe, uwalniany z aktywowanych płytek adenozynodifosforan (ADP, adenosine diphosphate) lub eksponowany na powierzchni aktywowanych limfocytów T ligand CD40 (CD40L, CD40 ligand) [12]. W konsekwencji aktywowane zostają zależne od wapnia enzymy, które zaburzają asyme- tryczny rozkład fosfolipidów w błonie komórkowej, czego skutkiem jest transport fosfatydyloseryny z wewnętrznej do zewnętrznej warstwy błony [12]. Jednocześnie dochodzi do destabilizacji cytoszkieletu komórki, co umożliwia formowanie i oddzielanie się z jej błony pęcherzyków MP [12]. Fosfatydyloseryna i inne ujemnie naładowane fosfolipidy obecne na powierzchni MP posiadają miejsca wiążące aktywne czynniki krzepnięcia, dzięki czemu odpowiadają za 50-100-krotnie wyższą aktywność prokoagulacyjną mikrocząstek niż aktywowanych płytek krwi [13]. Dodatkowo MP eksponują na swojej powierzchni czynnik tkankowy, dzięki czemu dostarczają podłoża do bezpośredniej aktywacji zewnątrzpochodnego toru krzepnięcia [10]. Postuluje się, że stanowią one najważniejsze źródło tak zwanego pochodzącego z krwi czynnika tkankowego (blood-borne tissue factor) [10]. Schemat powstawania MP i rodzaje eksponowanych na ich powierzchni antygenów przedstawiono na rycinach 1 i 2 [14].

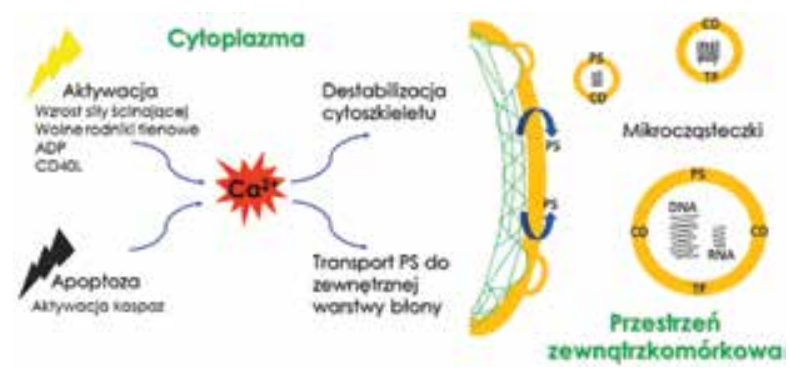

Rycina 1. Schemat powstawania mikrocząsteczek błon komórkowych; ADP (adenosine diphosphate) - adenozynodifosforan; CD40L - ligand CD40; CD (clusters of differentiation) - antygeny różnicowania komórkowego; DNA (deoxyribonucleic acid) - kwas deoksyrybonukleinowy; PS (phosphatidylserine) - fosfatydyloseryna; RNA (ribonucleic acid) - kwasy rybonukleinowy; TF (tissue factor) - czynnik tkankowy

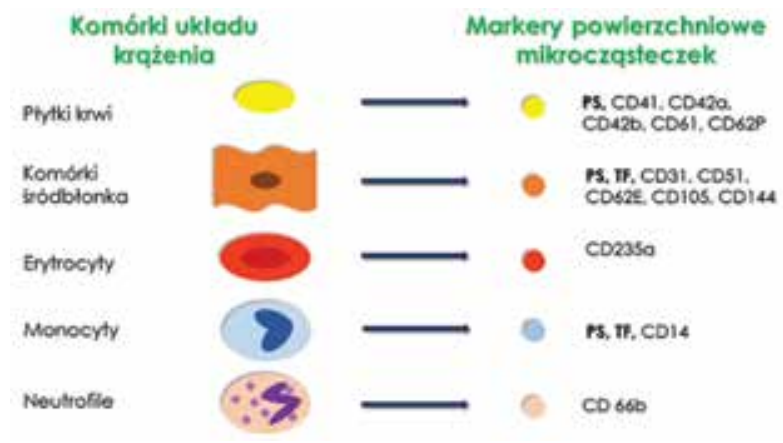

Rycina 2. Rodzaje mikrocząstek i eksponowane na ich powierzchni markery powierzchniowe (na podstawie [14]); CD (clusters of differentiation) - antygeny różnicowania komórkowego; PS (phosphatidylserine) - fosfatydyloseryna; TF (tissue factor) - czynnik tkankowy 


\section{Mikrocząsteczki w patogenezie chorób układu sercowo-naczyniowego}

Wykazano, że krążące PMP (aneksyna V, CD31+, CD36+) pobrane od zdrowych ochotników promowały adhezję płytek krwi do śródbłonka uszkodzonych naczyń tętniczych w warunkach in vitro, co było dodatkowo wzmagane przez zwiększenie siły ścinającej [15]. Rolę MP w powstawaniu zakrzepu na blaszce miażdżycowej in vivo postulują autorzy badania, w którym wykazano istotnie wyższe stężenie PMP (CD146+) i mikrocząsteczek z komórek śródbłonka (EMP, endothelial microparticles) (CD31+, CD42b+) w obrębie zmiany w tętnicy odpowiedzialnej za zawał serca (culprit lesion) niż we krwi obwodowej u pacjentów z zawałem serca z uniesieniem odcinka ST (STEMI, ST-elevation myocardial infarction) [16]. Co więcej stwierdzono istotne obniżenie stężenia badanych MP w osoczu po skutecznej przezskórnej interwencji wieńcowej (PCl, percutaneous coronary intervention) w tej grupie chorych [16]. Dalsze analizy zmian w zakresie stężeń poszczególnych typów MP mogą przyczynić się do pełniejszego zrozumienia patogenezy ostrych zespołów wieńcowych. W zakończonym niedawno badaniu klinicznym TIDE (Thrombus and Inflammation in sudden DEath ) oceniano związek między stężeniem MP pochodzących z różnych komórek (płytek krwi, komórek śródbłonka, leukocytów i erytrocytów) w obrębie culprit lesion i we krwi systemowej podczas zabiegu $\mathrm{PCl}$ u pacjentów, którzy przebyli nagłe zatrzymanie krążenia (SCA, sudden cardiac arrest) w mechanizmie migotania komór (VF, ventricular fibrillation), poprzedzone potwierdzonym angiograficznie zamknięciem naczynia wieńcowego i u pacjentów ze STEMI bez zaburzeń rytmu serca. Autorzy badania zaobserwowali wyższe stężenie EMP (CD144+) u pacjentów po SCA w porównaniu z grupą pacjentów bez zaburzeń rytmu. Na tej podstawie wysunęli hipotezę, że mechanizm ostrego zamknięcia tętnicy wieńcowej w tych dwóch sytuacjach klinicznych może być odmienny. Powyższe obserwacje wymagają jednak dalszych badań [17].

Po połączeniu się za pośrednictwem cząstek adhezyjnych z płytkami krwi, leukocytami i komórkami śródbłonka MP powodują ich dalszą aktywację, czego wyrazem jest między innymi produkcja prozapalnych cytokin [18]. Potwierdzono istotną statystycznie korelację stężenia PMP (CD41+) i EMP (CD144+) ze stężeniem markerów prozapalnych - interleukiny 6 (IL-6) i białka C-reaktywnego (CRP, C-reactive protein) u pacjentów ze stabilną chorobą wieńcową [19]. Co więcej w grupie pacjentów z zawałem serca wykazano, że krążące MP mogą przekształcać polimery CRP $\mathrm{w}$ jego promujące proces zapalny monomery, które po dostarczeniu do komórek śródbłonka inicjują w nich kaskadę procesu zapalnego [20]. Postuluje się również, że MP odgrywają istotną rolę w niszczeniu śródbłonka naczyń. Wykazano, że MP pochodzące z monocytów i komórek śródbłonka dostarczają do innych komórek aktywną kaspaze 1 i 3, kierując je na droge apoptozy [21, 22]. Ponadto zaobserwowano, że istnieje zależność między stężeniem EMP (aneksyna V+, CD31+) a dysfunkcją śródbłonka naczyniowego, ocenianego w badaniach angiograficznych na podstawie stopnia rozszerzenia naczyń po podaniu acetylocholiny [23]. W związku z opisanym prokoagulacyjnym, prozapalnym i proapoptotycznym działaniem mikrocząstek sugeruje się, że mogą one stanowić ogniwo łączące procesy zapalne i zakrzepowo-zatorowe, centralne mechanizmy leżące u podłoża patogenezy chorób układu sercowo-naczyniowego (CVD, cardiovascular diseases) [6, 18].

\section{Mikrocząsteczki - perspektywy wykorzystania w praktyce klinicznej}

Istnieje coraz więcej dowodów naukowych potwierdzających możliwość potencjalnego wykorzystania MP w diagnostyce najważniejszych powikłań miażdżycy tętnic i prognozowaniu ryzyka w przebiegu CVD.

Krążące MP są uznane za wysokiej czułości markery aktywacji i niszczenia zarówno krążących komórek krwi, jak i komórek śródbłonka [5]. Badanie stężenia MP w przebiegu epizodów zakrzepowo-zatorowych, takich jak zawał serca i udar niedokrwienny mózgu, jak również w stanach zwiększonego ryzyka zakrzepowo-zatorowego, towarzyszącego niestabilnej chorobie wieńcowej, przemijającym epizodom niedokrwiennym i krytycznemu niedokrwieniu kończyn dolnych, może mieć dużą wartość diagnostyczną [24-27]. Wykazano, że stężenie EMP (CD31+) w osoczu koreluje z nasileniem choroby niedokrwiennej serca (IHD, ischaemic heart disease); u pacjentów ze stabilną chorobą wieńcową stężenie EMP było istotnie wyższe niż w grupie kontrolnej, a jednocześnie istotnie niższe niż u chorych z ostrym zespołem wieńcowym [24]. W ostatniej grupie stwierdzono natomiast EMP w znacznie wyższych stężeniach w osoczu osób z zawałem serca w porównaniu z chorymi z niestabilną chorobą wieńcową. Autorzy badania postulują, że stężenie EMP może być użytecznym markerem oceny stopnia uszkodzenia śródbłonka naczyniowego w IHD. Podobny efekt zaobserwowano w przypadku PMP eksponujących na swojej powierzchni czynnik tkankowy (CD42+, 142+), których stężenie było najwyższe u osób z ostrym zespołem wieńcowym, niższe u pacjentów ze stabilną chorobą wieńcową i najniższe w grupie kontrolnej [25]. Zależność między stężeniem EMP (CD31+) i PMP (CD42+, CD142+) w osoczu a nasileniem IHD przedstawiono na rycinie 3. Podwyższone stężenie EMP stwierdzono także u pacjentów z ostrym niedokrwieniem ośrodkowego układu nerwowego w porównaniu z osobami zdrowymi [26]. Ponadto EMP o fenotypie CD144+/CD41a- korelowały z wielkością obszaru martwicy, ocenioną za pomocą tomografii komputerowej (CT, computed tomography) lub rezonansu magnetycznego 


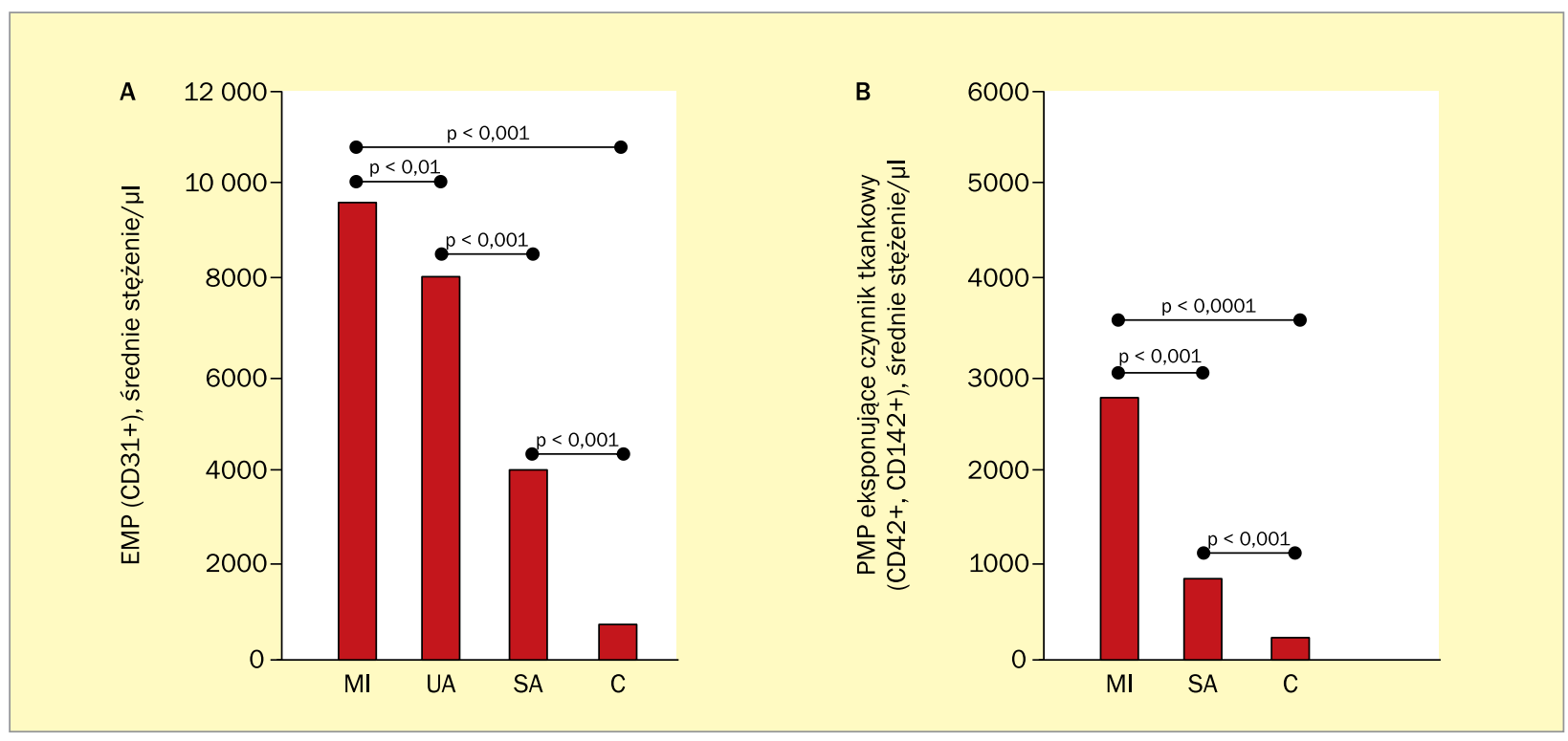

Rycina 3A, B. Zależność między stężeniem EMP (CD31+) i PMP (CD42+, CD142+) w osoczu a nasileniem choroby niedokrwiennej serca (na podstawie [24, 25]); C - kontrola (control); CD (clusters of differentiation) - antygeny różnicowania komórkowego; EMP (endothelial microparticles) - mikrocząsteczki z komórek śródbłonka; MI (myocardial infarction) - zawał serca; PMP (platelet microparticles) - mikrocząsteczki płytkowe; SA (stable angina) - stabilna choroba wieńcowa; UA (unstable angina) - niestabilna choroba wieńcowa

(MR, magnetic resonance), a EMP o fenotypie aneksyna $\mathrm{V}+/ \mathrm{CD} 62 \mathrm{E}+-\mathrm{z}$ podtypem udaru, ocenianym w klinicznej klasyfikacji niedokrwiennych zespołów udarowych Oxfordshire Community Stroke Project (OCSP) [26]. Stwierdzono również istotny związek między nasileniem choroby tętnic obwodowych a stężeniem PMP (CD62+, CD63+). U pacjentów z chromaniem przestankowym stężenie tych biomarkerów było wyższe niż w grupie osób zdrowych i wykazywało dalsze podwyższanie u chorych z krytycznym niedokrwieniem kończyn dolnych [27].

Zmiany stężenia i składu mikrocząsteczek mogą stać się obiecującym parametrem także w stratyfikacji ryzyka w przebiegu CVD. Korelację podwyższonego stężenia PMP $(C D 42 a+, C D 42 b+)$ z ryzykiem rozwoju IHD w ciągu 10 lat ocenianym według skali Framingham potwierdzono w populacji 190 zdrowych mężczyzn [28]. W prospektywnym badaniu, do którego włączono 200 pacjentów ze stabilną chorobą wieńcową, w 6-letniej obserwacji podwyższone stężenie EMP (aneksyna $\mathrm{V}+, \mathrm{CD} 31+$ ) wiązało się z istotnie wyższym ryzykiem zgonu z przyczyn sercowo-naczyniowych, konieczności rewaskularyzacji i wystąpienia pierwszego niekorzystnego incydentu sercowo-naczyniowego i mózgowego [29]. Na tej podstawie stwierdzono, że podwyższone stężenie MP jest niezależnym czynnikiem ryzyka sercowo-naczyniowego. U 51 pacjentów ze STEMI, leczonych pierwotną angioplastyką wieńcową, stężenie MP pochodzących z erytrocytów (CD235a+) było 2-krotnie wyższe niż u osób zdrowych i zwiększało ryzyko wystąpienia złożonego punk- tu końcowego (zgon lub konieczność resuscytacji, istotny hemodynamicznie częstoskurcz komorowy, zawał serca, konieczność rewaskularyzacji, ostra niewydolność serca lub ponowna hospitalizacja z przyczyn sercowo-naczyniowych) w 6-miesięcznej obserwacji [30]. Takiej korelacji nie stwierdzono natomiast w przypadku PMP. Podobne wyniki uzyskano w 3-letniej obserwacji u 300 pacjentów po udarze mózgu, u których stwierdzono korelację stężenia EMP (CD62E+) z liczbą niekorzystnych zdarzeń sercowo-naczyniowych i hospitalizacji [31]. Autorzy badań wskazują, że identyfikacja osób z podwyższonym stężeniem EMP, świadczącym o ogólnoustrojowej dysfunkcji komórek śródbłonka, może być pomocna w identyfikacji pacjentów o podwyższonym ryzyku zgonu z przyczyn sercowo-naczyniowych.

Istnieją również doniesienia o możliwej przydatności MP w ocenie skuteczności leczenia przeciwpłytkowego kwasem acetylosalicylowym i klopidogrelem u pacjentów ze stabilną chorobą wieńcową [32, 33]. Niższe stężenia PMP (CD42+), EMP (CD31+) i MP pochodzących z leukocytów $(\mathrm{CD} 11 \mathrm{a}+)$ zaobserwowano również w grupie pacjentów ze STEMI leczonych pierwotną $\mathrm{PCl}$, podczas której stosowano inhibitor receptora płytkowego IIb/IIla - abciximab -w porównaniu z chorymi nieotrzymującymi tego leku [34]. Efektu tego nie stwierdzono w przypadku eptifibatidu, co autorzy tłumaczą krótszym czasem połowicznego rozpadu tego leku i jego mniejszym powinowactwem do receptora. Jednocześnie ze względu na coraz lepiej udokumentowane prozapalne i prokoagulacyjne właściwości MP postuluje 


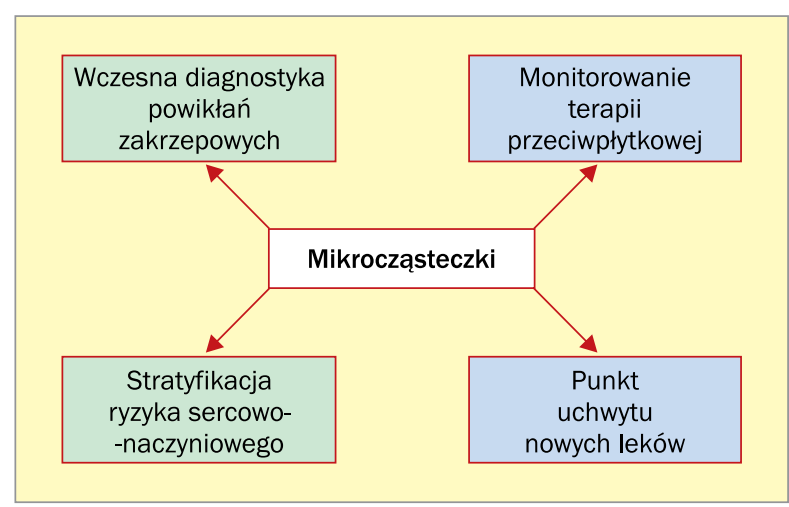

Rycina 4. Potencjalne wykorzystanie mikrocząsteczek w praktyce klinicznej

się, że cząsteczki te mogłyby same w sobie stanowić nowy cel terapeutyczny [35-39]. Udowodniono, że jednym z mechanizmów leżących u podłoża plejotropowego działania statyn w CVD jest ich wpływ na stężenie i skład MP [35, 36]. Podobny efekt zaobserwowano podczas leczenia inhibitorami receptorów aktywowanych czynnikami proliferacji peroksysomów (PPAR, peroxisome proliferator-activated receptors) - pioglitazonem $w$ grupie pacjentów z dyslipidemią i cukrzycą typu 2 [37] oraz bezafibratem u osób z układowymi chorobami tkanki łącznej i wtórnymi do leczenia glikokortykosteroidami zaburzeniami lipidowymi [38]. Wydaje się również, że witamina C, obok swoich właściwości antyoksydacyjnych, ma wpływ na stężenie MP, co potwierdzono w grupie pacjentów z cukrzycą typu 2 i dyslipidemią po 5 dniach suplementacji [39]. Podsumowanie potencjalnych możliwości wykorzystania MP w praktyce klinicznej przedstawiono na rycinie 4.

\section{Podsumowanie i potencjał dalszego rozwoju}

Obecnie mimo ponad 40 lat badań nad MP zrozumienie ich roli w patogenezie CVD, a tym samym możliwości wykorzystania jako biomarkerów w codziennej praktyce są ograniczone ze względu na brak wystandaryzowanej metody ich izolacji z materiałów biologicznych [40]. Zgromadzone dotychczas dowody naukowe potwierdzają wiele potencjalnych korzyści z badania stężenia MP w przebiegu CVD, u których podłoża leży przewlekły proces zapalny i które wiążą się ze zwiększonym ryzykiem powikłań zakrzepowo-zatorowych. W przyszłości pomiar stężenia MP z uwzględnieniem ich poszczególnych frakcji mógłby stać się elementem nieinwazyjnych testów diagnostycznych, pozwalających na wczesne rozpoznanie choroby i monitorowanie terapii u pacjentów wysokiego ryzyka sercowo-naczyniowego lub chorych nieodpowiadających na stosowane leczenie.

W czerwcu 2015 roku zakończył się koordynowany przez Akademickie Centrum Medyczne Uniwersytetu w Amsterdamie (AMC, Academic Medical Center University of Amsterdam) europejski projekt Metrological characterisation of micro-vesicles from body fluids as non-invasive diagnostic biomarkers (MetVes), który miał na celu opracowanie powtarzalnych, zarówno jakościowych, jak i ilościowych, metod oznaczania MP w uzyskanych próbkach [41]. Standaryzacja metod izolacji i oznaczania MP w płynach ustrojowych będzie milowym krokiem, który umożliwi dalszy rozwój badań nad tymi obiecującymi biomarkerami.

\section{Konflikt interesów}

Autorzy deklarują brak konfliktu interesów.

\section{Abstract}

Microparticles (MP) are considered a reliable marker of platelet activation and ongoing inflammation in vivo. Elevated levels of different subtypes of MP, including MP derived from platelets, endothelial cells and leukocytes have been observed in patients with ischaemic heart disease, stroke and peripheral artery disease. In these clinical entities the concentrations of MP correlated with the severity of the disease. According to some authors, MP may contribute to the development of atherosclerosis and its complications. On the other hand, there is substantial evidence that MP may be potentially used to diagnose the most relevant complications of atherosclerosis, as well as to prognose the individual cardiovascular risk and to monitor the response to antiplatelet therapy with acetylsalicylic acid and clopidogrel. Isolation and detection of MP in body fluids is an active research subject. Standardization of these procedures will allow better understanding of the role of MP in pathogenesis of cardiovascular disease, as well as implementing these novel promising biomarkers into every-day clinical practice.

Key words: microparticles, biomarkers, cardiovascular diseases, atherosclerosis

Folia Cardiologica 2016; 11, 2: 128-133 


\section{Piśmiennictwo}

1. Główny Urząd Statystyczny. Rocznik demograficzny 2014. Zakład Wydawnictw Statystycznych, Warszawa 2014.

2. Zdrojewski T., Rutkowski M., Bandosz P. i wsp. Prevalence and control of cardiovascular risk factors in Poland. Assumptions and objectives of the NATPOL 2011 Survey. Kardiol. Pol. 2013; 71: 381-392.

3. Lu H., Daugherty A. Atherosclerosis. Arterioscler. Thromb. Vasc. Biol. 2015; 35: 485-491.

4. Matsuzawa Y., Guddeti R.R., Kwon T.G., Lerman L.O., Lerman A. Secondary prevention strategy of cardiovascular disease using endothelial function testing. Circ. J. 2015; 79: 685-694.

5. Maślanka K. Fizjologiczna i patogenna aktywność mikrocząstek błon komórkowych. J. Transf. Med. 2010; 1: 9-17.

6. Barteneva N.S., Fasler-Kan E., Bernimoulin M. i wsp. Circulating microparticles: square the circle. BMC Cell Biol. 2013; 14: 23.

7. Risitano A., Beaulieu L.M., Vitseva O., Freedman J.E. Platelets and platelet-like particles mediate intercellular RNA transfer. Blood 2012; 119: 6288-6295.

8. Hunter M.P., Ismail N., Zhang X. i wsp. Detection of microRNA expression in human peripheral blood microvesicles. PLoS One 2008; 3: e3694.

9. Siljander P.R. Platelet-derived microparticles - an updated perspective. Thromb. Res. 2011; 127 (supl. 2): S30-33.

10. Owens A.P. III, Mackman N. Microparticles in hemostasis and thrombosis. Circ. Res. 2011; 108: 1284-1297.

11. Maślanka K., Michur H., Smoleńska-Sym G. Mikrocząstki błon komórkowych. Acta Haemat. Pol. 2009; 40: 481-491.

12. Morel 0., Morel N., Freyssinet J.M., Toti F. Platelet microparticles and vascular cells interactions: a checkpoint between the haemostatic and thrombotic responses. Platelets 2008; 19: 9-23.

13. Geddings J.E., Mackman N. Recently identified factors that regulate hemostasis and thrombosis. Thromb. Haemost. 2014; 111: 570-574.

14. Baron M., Boulanger C.M., Staels B., Tailleux A. Cell-derived microparticles in atherosclerosis: biomarkers and targets for pharmacological modulation? J. Cell Mol. Med. 2012; 16: 1365-1376.

15. Suades R., Padró T., Vilahur G., Badimon L. Circulating and platelet-derived microparticles in human blood enhance thrombosis on atherosclerotic plaques. Thromb Haemost. 2012; 108: 1208-1219.

16. Min P.K., Kim J.Y., Chung K.H. i wsp. Local increase in microparticles from the aspirate of culprit coronary arteries in patients with ST-segment elevation myocardial infarction. Atherosclerosis 2013; 227: 323-328.

17. Empana J.P., Boulanger C.M., Tafflet M. i wsp. Microparticles and sudden cardiac death due to coronary occlusion. The TIDE (Thrombus and Inflammation in sudden DEath) study. Eur. Heart J. Acute Cardiovasc. Care 2015; 4: 28-36.

18. Tushuizen M.E., Diamant M., Sturk A., Nieuwland R. Cell-derived microparticles in the pathogenesis of cardiovascular disease: friend or foe? Arterioscler. Thromb. Vasc. Biol. 2011; 31: 4-9.

19. Cui Y., Zheng L., Jiang M. i wsp. Circulating microparticles in patients with coronary heart disease and its correlation with interleukin- 6 and C-reactive protein. Mol. Biol. Rep. 2013; 40: 6437-6442.

20. Habersberger J., Strang F., Scheichl A. i wsp. Circulating microparticles generate and transport monomeric C-reactive protein in patients with myocardial infarction. Cardiovasc. Res. 2012; 96: 64-72.

21. Sarkar A., Mitra S., Mehta S., Raices R., Wewers M.D. Monocyte derived microvesicles deliver a cell death message via encapsulated caspase-1. PLoS One 2009; 4: e7140.

22. Abid Hussein M.N., Nieuwland R., Hau C.M., Evers L.M., Meesters E.W., Sturk A. Cell-derived microparticles contain caspase 3 in vitro and in vivo. J. Thromb. Haemost. 2005; 3: 888-896.

23. Werner N., Wassmann S., Ahlers P., Kosiol S., Nickenig G. Circulating CD31+/annexin V+ apoptotic microparticles correlate with coronary endothelial function in patients with coronary artery diseases. Arterioscler. Thromb. Vasc. Biol. 2006; 26: 112-116.

24. Bernal-Mizrachi L., Jy W., Jimenez J.J. i wsp. High levels of circulating endothelial microparticles in patients with acute coronary syndromes. Am. Heart J. 2003; 145: 962-970.

25. Stępień E., Stankiewicz E., Zalewski J., Godlewski J., Zmudka K., Wybrańska I. Number of microparticles generated during acute myocardial infarction and stable angina correlates with platelet activation. Arch. Med. Res. 2012; 43: 31-35.

26. Li P., Qin C. Elevated circulating VE-cadherin+CD144+endothelial microparticles in ischemic cerebrovascular disease. Thromb. Res. 2015; 135: 375-381.

27. Tan K.T., Tayebjee M.H., Lynd C., Blann A.D., Lip G.Y. Platelet microparticles and soluble $P$ selectin in peripheral artery disease: relationship to extent of disease and platelet activation markers. Ann. Med. 2005; 37: 61-66.

28. Ueba T., Nomura S., Inami N. i wsp. Plasma level of platelet-derived microparticles is associated with coronary heart disease risk score in healthy men. J. Atheroscler. Thromb. 2010; 17: 342-349.

29. Sinning J.M., Losch J., Walenta K., Böhm M., Nickenig G., Werner N. Circulating CD31+/Annexin V + microparticles correlate with cardiovascular outcomes. Eur. Heart J. 2011; 32: 2034-2041.

30. Giannopoulos G., Oudatzis G., Paterakis G. i wsp. Red blood cell and platelet microparticles in myocardial infarction patients treated with primary angioplasty. Int. J. Cardiol. 2014; 176: 145-150.

31. Lee S.T., Chu K., Jung K.H. i wsp. Circulating CD62E+ microparticles and cardiovascular outcomes. PLoS One 2012; 7: e35713.

32. Bulut D., Becker V., Mügge A. Acetylsalicylate reduces endothelial and platelet-derived microparticles in patients with coronary artery disease. Can. J. Physiol. Pharmacol. 2011; 89: 239-244.

33. França C.N., Pinheiro L.F., Izar M.C. i wsp. Endothelial progenitor cell mobilization and platelet microparticle release are influenced by clopidogrel plasma levels in stable coronary artery disease. Circ. J. 2012; 76: 729-736.

34. Morel O., Hugel B., Jesel L. i wsp. Circulating procoagulant microparticles and soluble GPV in myocardial infarction treated by primary percutaneous transluminal coronary angioplasty. A possible role for GPIlb-IIla antagonists. J. Thromb. Haemost. 2004; 2: 1118-1126.

35. Nomura S., Inami N., Shouzu A. i wsp. The effects of pitavastatin, eicosapentaenoic acid and combined therapy on platelet derived microparticles and adiponectin in hyperlipidemic, diabetic patients. Platelets 2009; 20: 16-22.

36. Tehrani S., Mobarrez F., Antovic A. i wsp. Atorvastatin has antithrombotic effects in patients with type 1 diabetes and dyslipidemia. Thromb. Res. 2010; 126: e225-231.

37. Esposito K., Ciotola M., Giugliano D. Pioglitazone reduces endothelial microparticles in the metabolic syndrome. Arterioscler. Thromb. Vasc. Biol. 2006; 26: 1926.

38. Kagawa H., Nomura S., Nagahama M., Ozaki Y., Fukuhara S. Effect of bezafibrate on soluble adhesion molecule and platelet activation markers in patients with connective tissue diseases and secondary hyperlipidemia. Clin. Appl. Thromb. Hemost. 2001; 7: 153-157.

39. Morel O., Jesel L., Hugel B. i wsp. Protective effects of vitamin C on endothelium damage and platelet activation during myocardial infarction in patients with sustained generation of circulating microparticles. J. Thromb. Haemost. 2003; 1: 171-177.

40. Yuana Y., Bertina B.M., Osanto S. Pre-analytical and analytical issues in the analysis of blood microparticles. Thromb. Haemost. 2011; 105: 396-408.

41. Metrological characterisation of micro-vesicles from body fluids as non-invasive diagnostic biomarkers. Dostępne na: http://metves.eu/. Data dostępu: 21.08.2015 r. 